\title{
EDITORIAL
}

\section{AINDA SOBRE A AVALIAÇÃO DOS PERIÓDICOS DE ENFERMAGEM}

Realizou-se em novembro, em São Paulo, o Encontro Internacional de Periódicos de Enfermagem, organizado pela UNIFESP, com a participação de representantes dos Estados Unidos no Journal of Advanced Nursing. Naquele evento, a Comissão de Avaliação Continuada da CAPES- área de enfermagem, apresentou uma nova matriz de classificação dos periódicos de enfermagem, modificando a apresentada, em julho, aos programas de pós-graduação, tendo como base informações procedentes dos relatórios desses programas, do levantamento feito pela $A B E n / R E B E n$ sobre a situação das publicações de enfermagem no Brasil, trabalho apresentado à comunidade cientifica durante o $52^{\circ} \mathrm{CBEn}$ e dos informes das escolas. A apresentação de uma matriz definitiva, deixando claro os critérios de excelência, permitirá que os editores, orientados por um instrumento, possam regular suas publicações. O critério utilizado para classificação de um periódico como de Circulação Internacional carece de maior clareza visto que se considerarmos a indexação como critério essencial os quatro periódicos brasileiros que estão no MEDLINE/INI merecem receber essa classificação; se considerarmos o número de exemplares de cada edição e sua distribuição a nivel internacional, provavelmente nenhum periódico poderia ser considerado como de Circulação Internacional.

É imprescindivel que as revistas cientificas de enfermagem sejam excelentes sob o ponto de vista da aceitação nacional, seus objetivos e vocação: algumas como órgão de divulgação institucional, outras no ensino, outras como divulgadoras da produção acadêmica. A par disto, é necessário que as publicaçōes expressem as tendências da produção científica da enfermagem brasileira e atinjam, verdadeiramente, a comunidade de enfermagem e que, ao mesmo tempo em que vão consolidando estas perspectivas, se expandam para outros paises e, em especial, para a América Latina e Caribe.

Só o reconhecimento externo evidenciado através da presença de revistas brasileiras nos indices bibliométricos é que deverá determinar o nível de circulação. Para atingirmos esta meta há um longo caminho a percorrer e a classificação de uma revista brasileira neste patamar, no momento, parece solução pontual para uma exigência que órgãos governamentais fazem aos cursos de pós-graduação ou seja a publicação de trabalhos científicos em periódicos internacionais. Para atender essa exigência é preciso que os pesquisadores brasileiros discutam e encontrem mecanismos que rompam as barreiras que dificultam o acesso de sua produção nesses periódicos.

Embora tenhamos divergências sobre os critérios de avaliação, reconhecemos 
que esse processo mobilizou os responsáveis para efetivarem mudanças nas revistas e determinou uma discussão sobre os parâmetros utilizados no interior das diversas instituições envolvidas com a produção e divulgação do conhecimento. A ABEn, desde 1998 , tem promovido, através do encontro de editores, uma discussão mais aberta com a CAPES sobre o tema e esta aproximação, ainda que tímida, tem sido muito produtiva.

Joel Rolim Mancia

Editor da REBEn 